\title{
Criteria of Initial Selection of Candidates for Artistic Gymnastics
}

DOI: $10.2478 / \mathrm{v} 10131-010-0008-7$

\author{
Authors' Contribution: \\ A - Study Design \\ B - Data Collection \\ C - Statistical Analysis \\ D - Data Interpretation \\ E - Manuscript Preparation \\ F - Literature Search
Kazimierz Kochanowicz ${ }^{(A, B, C, D, F, G)}$, Andrzej Kochanowicz ${ }^{(B, C, D, E)}$
Jedrzej Sniadecki Academy of Physical Education and Sport in Gdansk, Poland

$\mathrm{G}$ - Funds Collection

Key words: selection for sport, somatic build, physical fitness.

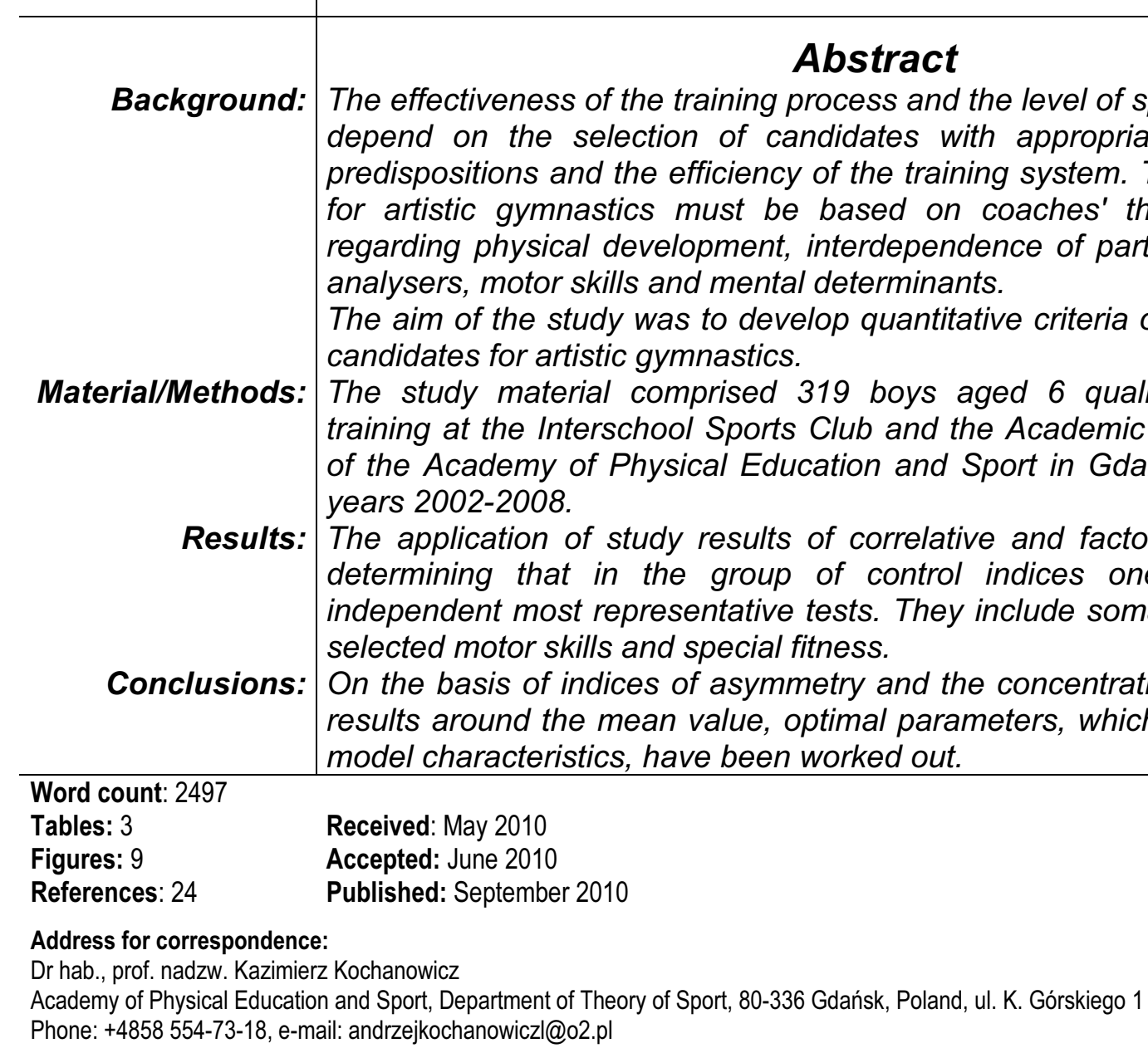




\section{Introduction}

High progressiveness of the obtained results in various sports disciplines poses multi-aspect requirements for coaches. In order to meet them, it is necessary to explore solutions aiming at specifying factors which determine athletes' value and preparation [1,2,3,4,5]. Because of structural complexity and diversity in the dynamics of exercises performed on various apparatuses, artistic gymnastics is a discipline with special demands on athletes' organisms.

Factors determining a sports result include the so-called internal ones, which comprise athletes' psycho-physical capabilities, and the external ones resulting from environmental variables, which comprise rules, regulations, programmes, training methods and means, a tournament calendar, etc. That is why scientific research and prominent specialists point to the indispensability of a special selection of candidates with specific predispositions, with an ability to develop and the prospect to achieve best results internationally $[6,7,8,9]$.

Admittedly, the selection of candidates for artistic gymnastics and directing them in the process of sports training stems from willingness not only to achieve sports mastery but also to improve general physical fitness for better well-being, compensation resulting from lack of physical activity, doctor's recommendations, etc. In the current social development, directing people who take exercise in their physical activity is one of the most important issues requiring explanation.

Due to genetic determination and the influence of the environment, each person develops individually. Hence, the selection of children for artistic gymnastics must take into consideration a possibility of verification or changes in the originally adopted aims. Many a time parents bring children to a gymnastic club in order to stimulate a young organism at the age of 5-7 to physical activity or to create conditions necessary to practise another sports discipline. This results from the fact that at the kindergarten or early school age - at the time of starting the training process - it is difficult to recognise a future Olympic champion or a world record breaker. In such circumstances the significance of a coach grows, as on the basis of his knowledge of the functioning of an organism, the speed of biological and mental development, he builds up an athlete's personality and physical fitness through a systematic and logically programmed training, thus creating a sports talent.

Candidates' initial selection is the beginning of their individual and supposedly long sports career. Pointing the path of development, bodily changes taking place and achieved motor skill to each practising person is an important task of all coaches. The effectiveness of a training process and the level of sports mastery of future national representatives will depend on a thorough assessment of predispositions of practising persons at the stage of selection and initial training.

Balsevich [10], Kochanowicz [11], Platonov [1], Raczek [12], Sawczyn [13], Volkov [14], Zaporożanow, Sozański [15] and others stress that at this stage a coach faces a vital and responsible mission - to choose the most talented children from a mass who start their sports training, who will achieve their sports mastery by developing their predispositions.

Due to different requirements resulting from the construction of particular gymnastic apparatuses and a multitude of exercises diversified in the structure of movement and the level of difficulty performed in various plains, obtaining high sports results in gymnastics is determined by a long-term training period. The optimal period counted from the beginning of specialist training to achieving the mastery level is $5-7$ years in women and $8-10$ years in men $[16,17,18,19]$.

The aim of the study was to develop quantitative criteria of initial selection of candidates for artistic gymnastics.

\section{Material and methods}

The study material comprised 319 boys aged 6 qualified for gymnastic training at the Interschool Sports Club and the Academic Sports Association of the Academy of Physical Education and Sport in Gdańsk in 1998 and in years 2002-2008 (Tab.1). 
Tab 1. The number of boys qualified for sports training in gymnastics

\begin{tabular}{|c|c|c|c|c|c|c|c|c|}
\hline Year of study & 1998 & 2002 & 2003 & 2004 & 2005 & 2006 & 2007 & 2008 \\
\hline $\begin{array}{c}\text { Number of } \\
\text { subjects }\end{array}$ & 50 & 30 & 20 & 70 & 48 & 60 & 20 & 21 \\
\hline
\end{tabular}

Qualification for initial sports training took place on the basis of somatic build and physical fitness indices. Among somatic build indices, height and body mass, the width of shoulder and pelvic girdles were considered.

To assess physical fitness, the following indices were used:

- pull-ups on a bar from hanging (the number of full pull-ups counted);

- time of hanging from a bar with bent arms (measured in seconds);

- maintaining horizontally straightened legs in hanging with one's back to wall bars (counted in seconds);

- walking on a balance beam and jumping off at a mattress (assessed in a 10-point scale);

- forward bend (measured in centimetres).

All measurements were taken in the same conditions ensuring their uniformity. The study was carried out in accordance with the organisational-methodological description presented by K. Kochanowicz in 1998 [5].

The results were subject to a statistical analysis with the use of means, minimal and maximal values, standard deviation and statistical distribution.

\section{Results}

An analysis of the study results as to the indices of somatic build showed that extensively diversified boys were qualified for artistic gymnastics at the initial stage of training. The standard deviation amounted to $3.5-6.8 \mathrm{~cm}$. The greatest diversification in height was noted in boys starting the training process in 2005. The tallest boy was $139 \mathrm{~cm}$ tall and the shortest one $105 \mathrm{~cm}$ (Fig. 1).

The difference between the maximal and the minimal value was $34 \mathrm{~cm}$. The slightest differentiation among the subjects was noted in 2002 and 2007. The standard deviation was $3.5 \mathrm{~cm}$. The difference between the tallest and the shortest boys was $12 \mathrm{~cm}$. Mean values amounted to $118-126 \mathrm{~cm}$.

The greatest differentiation among boys in body mass was $24.6 \mathrm{~kg}$ - it was noted in 2006 (Fig. 2). The highest BMI was held by a boy who weighed $39.2 \mathrm{~kg}$. The lightest boy also started training in the same year. His body mass was $14.6 \mathrm{~kg}$. Mean values in the studied years amounted to from 21 to $24.5 \mathrm{~kg}$. Standard deviation oscillated from 2.3 to $3.9 \mathrm{~kg}$. The slightest differentiation among the studied boys was noted in 1998 and 2008. It was $8.5 \mathrm{~kg}$ with the standard deviation at $2.3-2.4 \mathrm{~kg}$. 


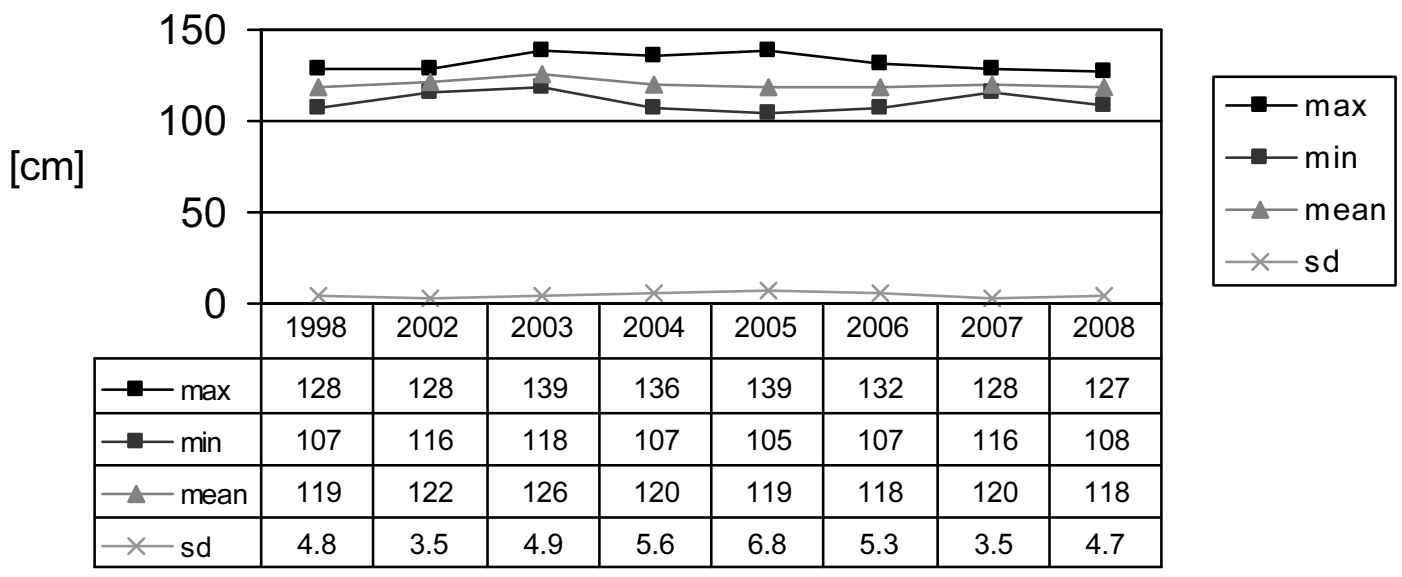

Fig. 1. Height of 6-year-old candidates for gymnastics in 1998-2008

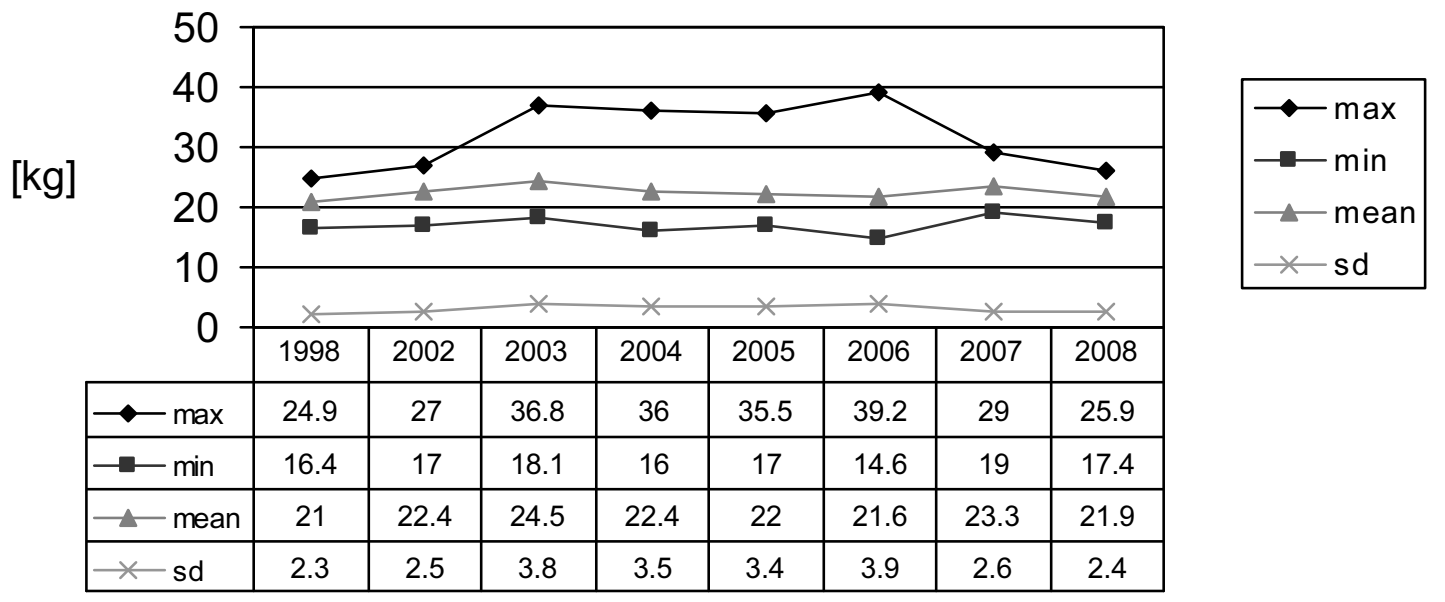

Fig. 2. Body mass of 6-year-old candidates for gymnastics in 1998-2008

The index of shoulder and pelvic girdles width less distinguished young novice gymnasts (Fig. 3-4). The greatest differences in the width of the shoulder girdle was noted in 1998; 2004 - they were $7.6-7.7 \mathrm{~cm}$, and of the pelvic girdle in $2005-4.1 \mathrm{~cm}$. Standard deviation in the parameters of the pelvic girdle width was running at $1.0-1.9 \mathrm{~cm}$. Its highest value was noted in 1998 and the lowest one in 2002. The lowest standard deviation in the pelvic girdle width was noted in 2003. It was $0.6 \mathrm{~cm}$, and the highest one in 2005 . It was $1.2 \mathrm{~cm}$.

The level of physical fitness, assessed on the basis of the number of pull-ups on a bar, the duration of hang with bent arms, the duration of keeping horizontally straightened legs in a hang with one's back to wall bars, walking on a balance beam and forward bend, was specific in each study year. The most pull-ups on a bar, as many as 11, were achieved by a 6-year-old boy in 1998 . In that year also the greatest differentiation in the group was noted. Standard deviation was 2.6 pull-ups. The slightest differentiation and the lowest level results were noted in 2003. A boy who pulled up 3 times achieved the highest value. By contrast, the highest level of mean values was noted in $2007-4.16$ (Fig. 5). It needs to be emphasised that it was the only year throughout the studied period when all candidates for gymnastics pulled up on a bar at least twice. 


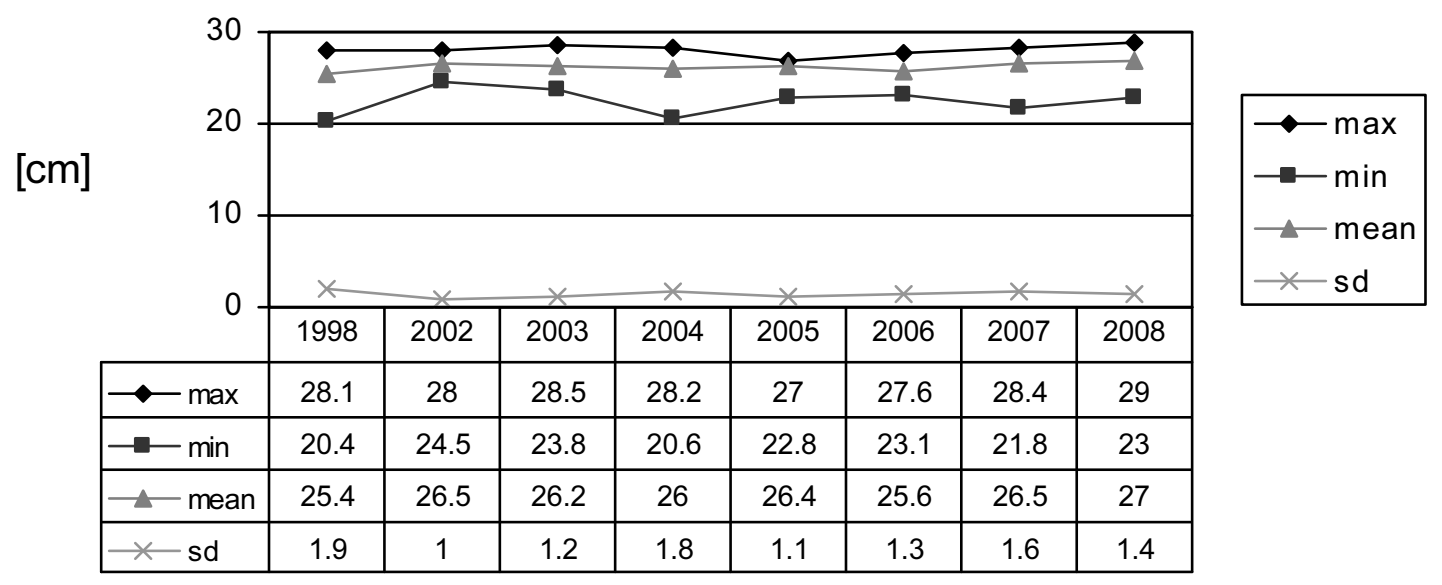

Fig. 3. Shoulder girdle width of 6-year-old candidates for gymnastics in 1998-2008

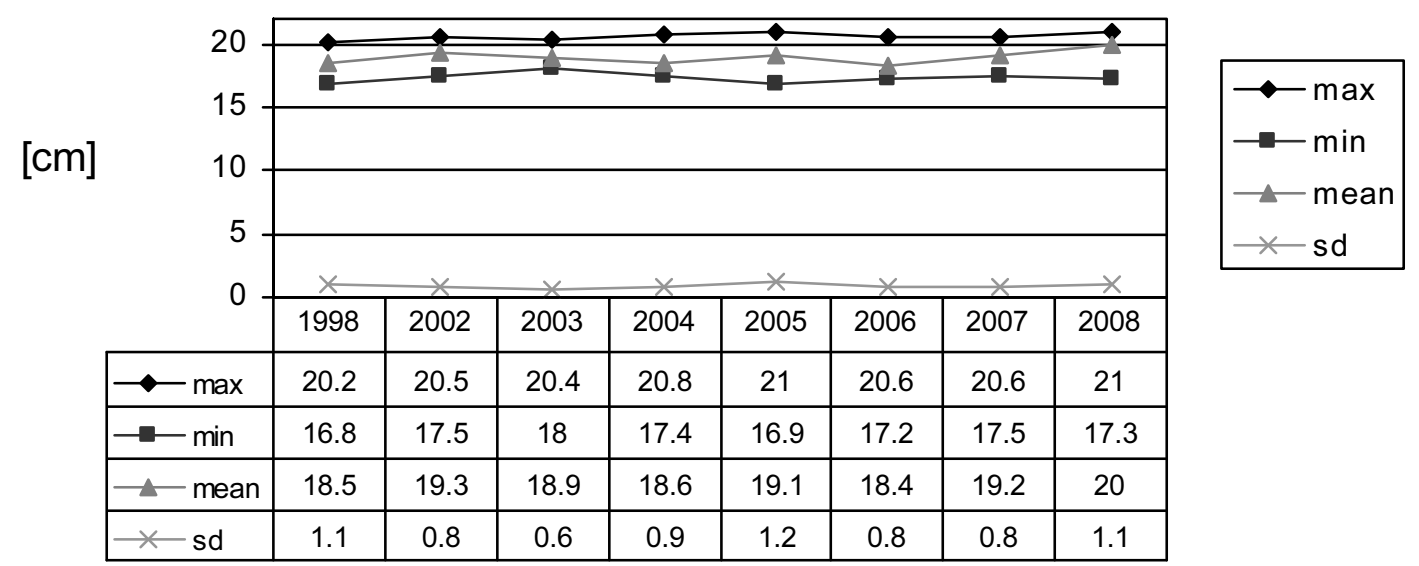

Fig. 4. Pelvic girdle width of 6-year-old candidates for gymnastics in 1998-2008

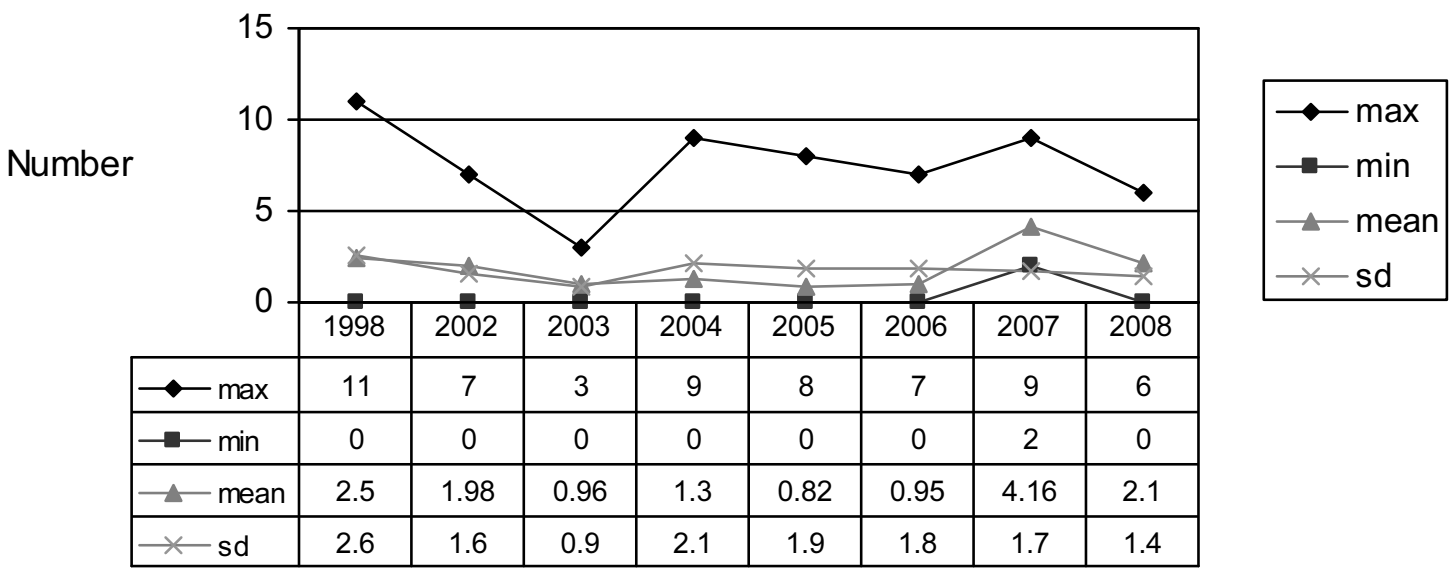

Fig. 5. The number of pull-ups on a bar of 6-year-old candidates for gymnastics in 1998-2008

Boys kept hanging from a bar with bent arms the longest in 2008. The mean value for the group was $17.8 \mathrm{sec}$. compared to $12-13 \mathrm{sec}$. in other years. The lowest value was achieved by a boy hanging from a bar for $78 \mathrm{~s}$ (Fig. 6). Here also the greatest differentiation in the results was noted, which is proved by standard deviation (17.2 s). The slightest differentiation in the results was noted in 2002, when standard deviation was $5.1 \mathrm{~s}$. 


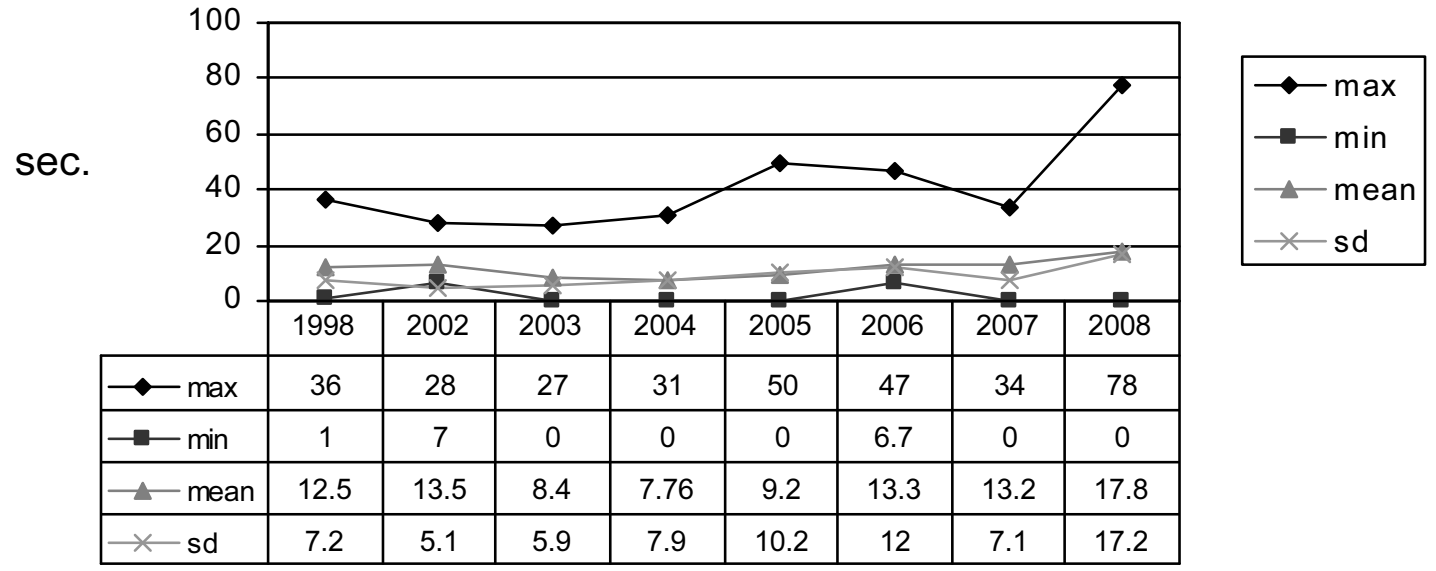

Fig. 6. Time of hanging from a bar of 6-year-old candidates for gymnastics in 1998-2008

Keeping straightened legs horizontally in a hang with one's back to wall bars proved substantial differentiation in particular years of the study (Fig. 7). Boys presented the highest level in 2007, definitely exceeding their peers from other years. Also standard deviation was the greatest then (15.2 sec.), indicating a significant differentiation in the results. This is also confirmed by the mean value of $33.36 \mathrm{sec}$., compared to $6-12 \mathrm{sec}$. in the other years, as well as the maximal value $62 \mathrm{sec}$., compared to 10-36 sec., obtained by novice gymnasts of other years.

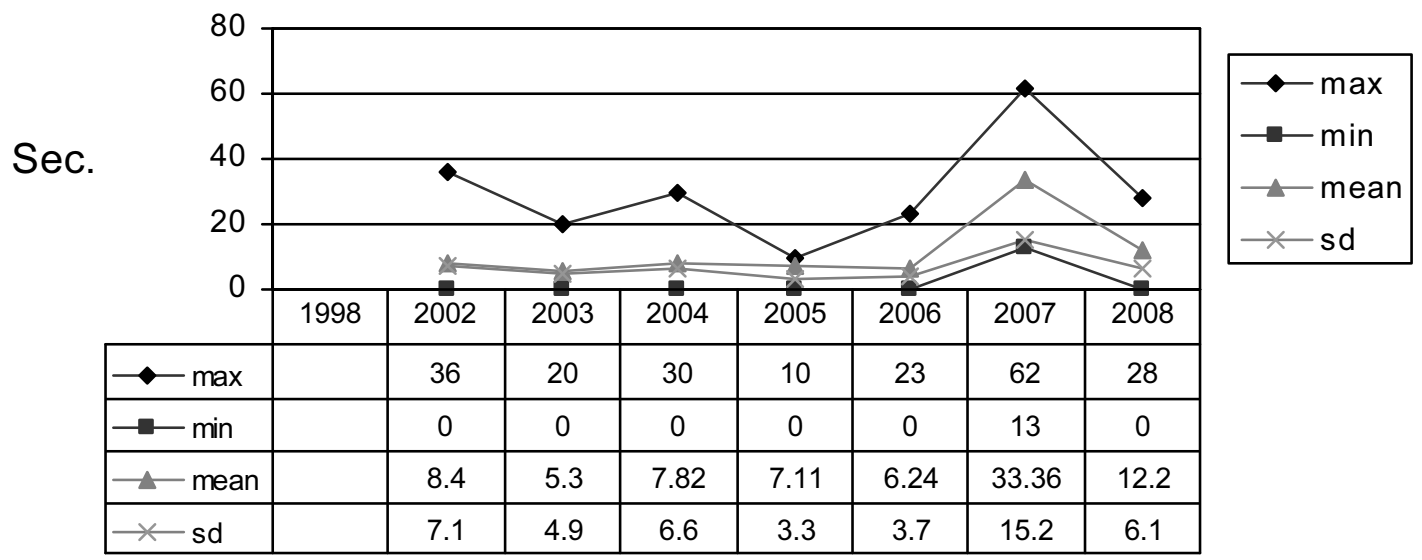

Fig. 7. Time of keeping legs horizontally straightened in hang with one's back to wall bars of 6-year-old candidates for gymnastics in 1998-2008

The studied boys' walking on a balance beam with a jump off at a mattress was assessed at a similar level in all years (Fig. 8). Mean values were running from 5.8 to 7.9 points in each year. Standard deviation amounted to from 1.94 to 2.19 pts. One needs to stress, however, that in 2002 and 2004 the span of the results between the best and the worst one was 9 pts. 


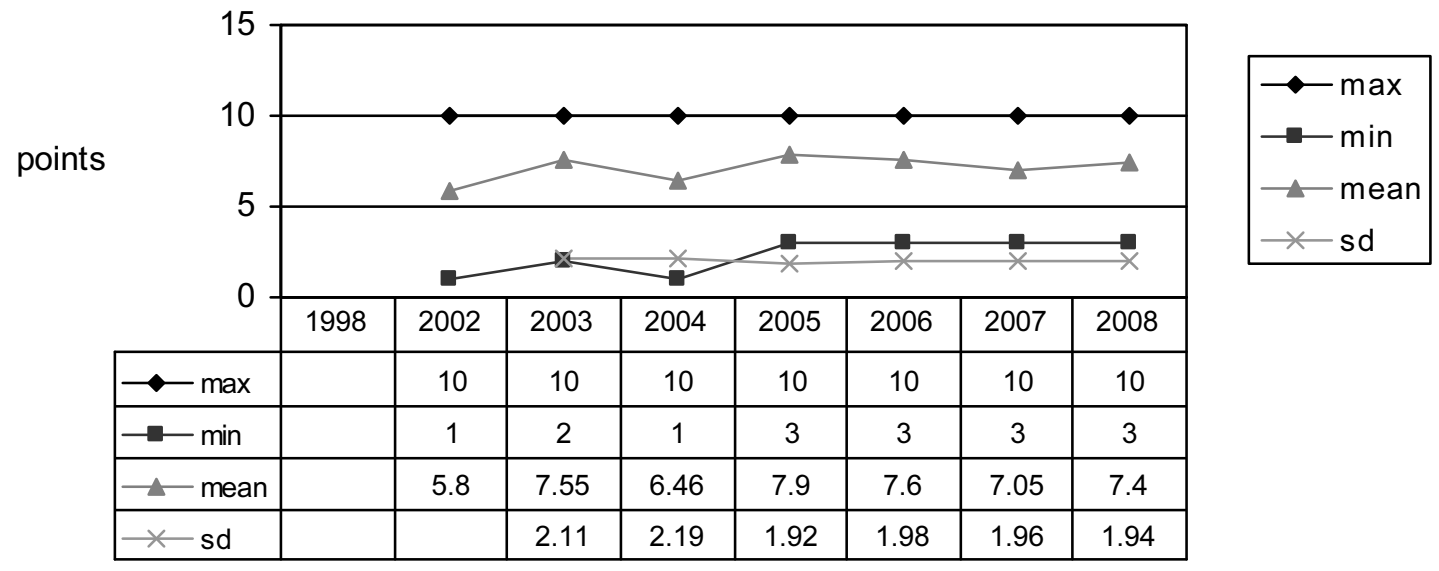

Fig. 8. Walking on a balance beam by 6-year-old candidates for gymnastics in 1998-2008

The flexibility index defined by a forward bend showed a significant differentiation between the individual years as well as within each group of boys from a given year. It was from 2 to $18 \mathrm{~cm}$. The greatest value of flexibility, which was $9.5 \mathrm{~cm}$, was exhibited by the studied boys in 2002 (Fig. 9).

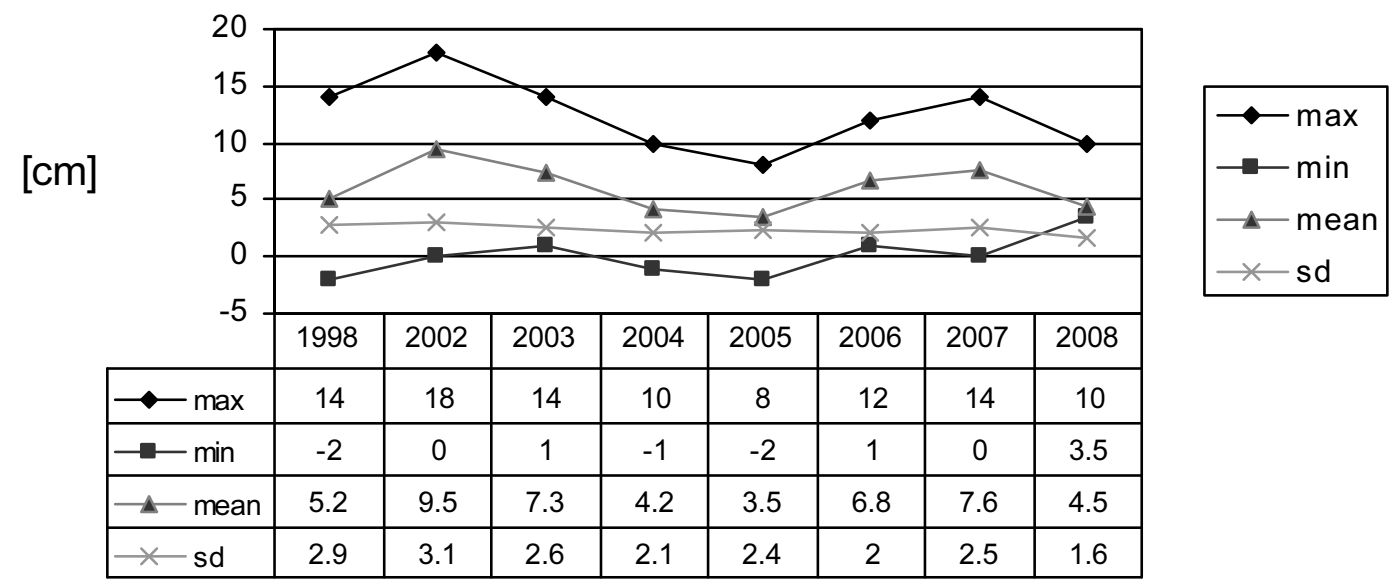

Fig. 9. Forward bend of 6-year-old candidates for gymnastics in 1998-2008

\section{Discussion and conclusions}

Initial selection of candidates for particular sports disciplines requires applying practical methods as to the assessment of the duration and necessary condition to run it $[2,16,17]$.

It seems that the accuracy of choice and the ease of carrying out the selection attempts is the basic prerequisite of popularity among coaches, instructors and physical education teachers. Zaporożanow, Sozański [15], Ważny [8], Volkov [14] and others draw attention to the need to run a promotional activity through mass media, posters, leaflets, shows, etc. in order to raise interest in a given sports discipline.

Putting together various modes of selections used in studies by Cichalewska [19], Janowski [20], A. Kochanowicz [21], Kruczkowski [22], Rozin [23], Sawczyn [13], Szczepańska [24] allows singling out what is common and seems the most valuable - the multi-stage nature of initial selection giving an opportunity to assess predispositions to gymnastics with designing an individual 
path of sports development. The current study results extend the range of information on the somatic build and physical fitness of boys taking up training in artistic gymnastics throughout the period of 10 years.

The application of the above study results as well as earlier observations presented in works by K. Kochanowicz [5,11], Sawczyn [7,13] or Kruczkowski [22], at the initial stage of selection for artistic gymnastics allowed us to single out in the somatic build the indices of the body height and mass, shoulder and pelvic girdles widths.

On the basis of statistical distribution, with consideration for minimal, maximal and mean values, a point scale has been worked out to allow obtaining information on the quantitative characteristics of the studied gymnasts (Tab. 2.). It enabled choosing from a group of practising persons the ones who manifest optimal development capabilities insofar as the demands posed in artistic gymnastics. For example, the highest point values for the body height have been determined in the range of $120 \mathrm{~cm}-119 \mathrm{~cm}$ and lower, while for the body mass $-20 \mathrm{~kg}$ and less.

Tab. 2. Optimal parameters of the somatic build in 6-year-old gymnasts

\begin{tabular}{|c|c|c|c|c|c|}
\hline \multirow{2}{*}{ Somatic build indices } & \multicolumn{5}{|c|}{ Points } \\
\cline { 2 - 6 } & 20 & 40 & 60 & 80 & 100 \\
\hline K 1- Body height (cm) & $130-132$ & $127-129$ & $124-126$ & $121-123$ & $\begin{array}{c}120-119 \\
\text { and less }\end{array}$ \\
\hline K2 - Body mass (kg) & $28-27$ & $26-25$ & $24-23$ & $22-21$ & 20 and less \\
\hline K3 - Pelvic width (cm) & 22 & 21 & 20 & 19 & 18 \\
\hline K4 - Shoulder width (cm) & $29-30$ & $28-29$ & $27-28$ & $26-27$ & $25-26$ \\
\hline
\end{tabular}

$$
K_{s m}=\frac{K_{1}+K_{2}+K_{3}+K_{4}}{4}+15
$$

The maximal number of points which a gymnast can obtain for the somatic build (including a bonus) is 115 points.

Owing to a mathematical analysis, the results of a systematically conducted control of physical fitness of prospective gymnasts allowed working out optimal norms (Tab. 3). They enable determining athletes' predispositions insofar as the posed requirements at the initial stage of sports training. Each attempt characterised by various values (duration, the number of repetitions, experts' assessment) has been presented in a uniform point scale. It enables the assessment of the level of development of particular indices of physical fitness with reference to one another. For instance, to obtain 100 points, one needs to pull up ten times on a bar, hang for $30 \mathrm{sec}$. from a bar with bent arms, bend forward while standing reaching $12 \mathrm{~cm}$ below the ground level, etc. 
Tab. 3. Optimal parameters of physical fitness in 6-year-old gymnasts

\begin{tabular}{|l|c|c|c|c|c|c|c|c|c|c|}
\hline \multirow{2}{*}{ Parameters of physical fitness } & \multicolumn{10}{|c|}{ Points } \\
\cline { 2 - 13 } & 100 & 90 & 80 & 70 & 60 & 50 & 40 & 30 & 20 & 10 \\
\hline K1 - pull-ups on a bar & 10 & 9 & 8 & 7 & 6 & 5 & 4 & 3 & 2 & 1 \\
\hline K2 - time of hanging with bent arms & 30 & 28 & 25 & 22 & 19 & 16 & 13 & 10 & 7 & 5 \\
\hline K3 - flexibility in forward bend & 12 & 11 & 10 & 9 & 8 & 7 & 6 & 5 & 4 & 3 \\
\hline $\begin{array}{l}\text { K4 - keeping horizontally straightened legs in } \\
\text { hanging from wall bars }\end{array}$ & 50 & 45 & 40 & 35 & 30 & 25 & 20 & 15 & 10 & 5 \\
\hline K5 - walking on a balance beam & 9.5 & 9.0 & 8.0 & 7.5 & 7.0 & 6.5 & 6.0 & 5.5 & 5.0 & 4.0 \\
\hline
\end{tabular}

The index of integrated assessment of physical fitness may be presented in the following way :

$$
K_{F}=\frac{K_{1}+K_{2}+K_{3}+K_{4}+K_{5}}{5}
$$

The point list of the studied indices allows determining an individual profile of prospective gymnasts' physical fitness.

Due to their universal meaning, control indices regarding physical fitness of gymnastics novices should be considered with careful attention. Information on the level of motor fitness and motor skills plays an important role at all stages of a sports career. It helps in selection of appropriate training methods and means as well as in programming the most accurate gymnastic routines adapted for competitors' individual capabilities.

On the basis of quantitative criteria of the assessment of somatic build and physical fitness, there is a possibility to evaluate the athletes' talent and to plan appropriate stages of sports training.

\section{References}

1. Platonov VN. Basic Obschaya teorya podgotovki sportsmenov $v$ olimpiyskom sporte [Theory of sport preparation at the Olympic level]. Kiev: Olimpijskaya Literatura; 1997 [in Russian].

2. Sozański H. Zróżnicowanie rozwoju sportowego młodocianych zawodników w zależności od rodzaju treningu [Diversity of sport development in young athletes' group, depending on training methods]. Warszawa: AWF; 1996 [in Polish].

3. Zaporozhanov VA. Kontrol w sportivnoy trenirovke [Control in sport training]. Kiev: Zdorovya; 1988 [in Russian].

4. Starosta W. Dobór i selekcja sportowa - problem badawczy [Sport assortment and selection - research issue] In: Wybrane problemy doboru i selekcji w sporcie [Selected issues of assortment and selection in sport] vol. 1. Warszawa: Instytut Sportu; 1985 [in Polish].

5. Kochanowicz K. Kompleksowa kontrola w gimnastyce sportowej [The comprehensive control in artistic gymnastic]. Gdańsk: AWF; 1998 [in Polish].

6. Pilicz S. Wybrane zagadnienie selekcji w sporcie [Chosen issues of selection in sport]. Warszawa: Biblioteka trenera PKOL; 1971 [in Polish].

7. Sawczyn S. Rozwój fizyczny i sprawność fizyczna gimnastyków w wieku 10-15 lat [Physical development and physical fitness in 10-15-year-old gymnasts]. PhD Dissertation. Poznań: AWF; 1985 [in Polish].

8. Ważny Z. Współczesny system szkolenia w sporcie wyczynowym [Contemporary system of training in professional sport]. Warszawa: SiT; 1981 [in Polish]. 
9. Wolański N. Metody kontroli i normy rozwoju dzieci i młodzieży [Control methods and development norms of children and youth]. Warszawa: PZWL; 1975 [in Polish].

10. Balsevich VK. Ontokinesiologia cheloveka [Human onto-kinesiology]. Moskwa: Teoria i Praktika Fizicheskoi Kultury; 2000 [in Russian].

11. Kochanowicz K. Podstawy kierowania procesem szkolenia sportowego w gimnastyce [The basis of directing of sports training process in gymnastics]. Gdańsk: AWFiS; 2006 [in Polish].

12. Raczek J. Podstawy szkolenia sportowego dzieci i młodzieży [The basis of sport schooling of children and youth]. Warszawa: RCMSzKFiS; 1991 [in Polish].

13. Sawczyn S. Obciążenia treningowe $w$ gimnastyce sportowej $w$ wieloletnim procesie przygotowań [Training loads in artistic gymnastics during a long-term preparation cycle]. Gdańsk: AWFiS; 2000 [in Polish].

14. Volkov LV. Teoria sportivnogo otbora; sposobnosti, odarennost, talant. Kiev: Wiezha, 1997 [in Russian].

15. Zaporożanow W, Sozański H. Dobór i kwalifikacja do sportu [Assortment and qualification to sport]. Warszawa: COSRCMSzKFiS; 1997 [in Polish].

16. Smolevskij VM, Gaverdovskij JK. Sportivnaja gimnastika [Artistic gymnastics]. Kiev: Olimpijskaja Literatura; 1999 [in Russian].

17. Woynarowska B. Wybrane problemy sportu dzieci i młodzieży [Selected issues of children and youth sport]. In: Dziak A, Nazar K, editors. Medycyna sportowa [Sports medicine]. Warszawa: PTMS;1991, 234-279 [in Polish].

18. Ziemilska A. Sport dzieci i młodzieży; uwarunkowania i konsekwencje. Seria: Z warsztatów badawczych [Children and youth sport - determinants and consequences]. Warszawa: AWF; 1987 [in Polish].

19. Ciechalewska A, editor. Dobór, selekcja i rozwój dziewcząt uprawiających gimnastykę sportową [Assortment, selection process and development of young female athletes participating in artistic gymnastics]. Zeszyty Naukowe AWF Kraków 1983;28:111 [in Polish].

20. Janowski D. Selekcja i trening młodocianych gimnastyków [Selection and training of young gymnasts]. Warszawa: SiT; 1972 [in Polish].

21. Kochanowicz A. Sprawność fizyczna a efektywność przygotowania technicznego gimnastyków na etapie ukierunkowanym [Physical fitness vs efficiency of technical preparation of gymnasts at the directed stage]. PhD Dissertaiton. Gdańsk: AWFiS; 2010 [in Polish].

22. Kruczkowski D. Dobór i selekcja na etapie wszechstronnego i ukierunkowanego treningu chłopców w wieku 7-10 lat uprawiających gimnastykę sportowa [Assortment and selection at the comprehensive and directed stage of training in 7-10-year-old boys participating in artistic gymnastics]. PhD Dissertation. Gdańsk: AWF; 1998 [in Polish].

23. Rozin EJ. Sposoby ocenki tehnicheskoj podgotovlennosti gimnastov [Methods of technical preparation evaluation in a group of gymnasts]. Gimnastika, Fizkultura i Sport 1974:1:10-13 [in Russian].

24. Szczepańska K. Dobór dziewcząt do gimnastyki artystycznej [Selection process of girls to rhythmic gymnastics]. Studia i Monografie nr 9. Warszawa: AWF; 1977 [in Polish]. 